\title{
Indonesian Military Court Law Absolute Competence through Equality before the Law Principle
}

\author{
Jamin Ginting ${ }^{1, *}$ and Axel Victor Christian ${ }^{2}$ \\ ${ }^{1}$ Lecturer at Faculty of Law, Pelita Harapan University, Tangerang, Indonesia \\ ${ }^{2}$ Alumni at Faculty of Law, Pelita Harapan University, Tangerang, Indonesia
}

\begin{abstract}
Law Number 31 Year 1997 regulates the jurisdiction of the Indonesian Military Court to handle military members who commit a general crime and military crime based on the Indonesian Penal Code and Indonesian Military Code respectively. However, the General Court also retains jurisdiction over the military members who commit a general crime based on the Indonesian Penal Code. In comparison, Indonesian Civilians who commit a general crime based on the Indonesian Penal Code are only under the General Court.

This condition is against the principle of equality before the law as stated in Article $28 \mathrm{D} .1$ of the 1945 Constitution. Indonesia as a state of law must hold this principle. Authors use normative legal research to solve the law issues by reviewing the related laws and the law principles in Indonesia.
\end{abstract}

Keywords: Military Court Law, General Court, Equality Before the Law, State Law, Privileges.

\section{INTRODUCTION}

The existence of a Military Court in Indonesia is recognized in Article 24 Verse 2 of the 1945 Constitution, stipulating that the courts under the Supreme Court. With power residing from the Supreme Court of Indonesia and the position below the Supreme Court of Indonesia, as a legal consequence, Military Courts in Indonesia are the same in its level as any other General Courts such as civil courts for nonmilitary members. The Military Court in Indonesia operates under Law Number 31 Year 1997 Concerning Military Court [Military Court Law"], in which its jurisdiction is laid out under Article 9 Verse 1 which stipulates that the court's jurisdiction is for military members or civilians considered as military members that have committed an alleged crime. The crimes also include general crime in "Indonesian Penal Code" ["IPC"].

This means the Military Court's jurisdiction is to adjudicate cases where a military member commits an alleged crime regardless of whether the crime falls within general crime or military crimes. Military members are subject to two court jurisdictions since the General Courts also retain jurisdiction for General Crime. This is further strengthened by Article 11 of Military Court Law which acknowledges that for a criminal crime to be conducted there can be more than one court to exercise its jurisdiction over the case. Article 11 supports Article 9 in this matter by

*Address correspondence to this author at the Lecturer at Faculty of Law, Pelita Harapan University, Tangerang, Indonesia;

E-mail: jamin.ginting@uph.edu acknowledging the possibilities that a military member may be retained by more than one court. However, Article 11 will not be the main legal issue since the writer writes this paper in concerns of Article 9. Consequently, the military members will enjoy privileges as surely one of the courts will be more beneficial than the others.

After the reformation, the government wanted the military personal subject to fair treatment; where military members who commit a general crime are subject to General Court and military crimes subject to Military Court. It is through People's Representative Decision Number VII/2000 in which the government decides for a recall on the Military Court's adjudication to provide fair treatment and prevention of privilege. The follow-up was through Article 64 of Law Number 34 Year 2004 Regarding Indonesia Armed Forces ["Indonesia Armed Forces Law"] where military members who commit general crime are subject to General Court and military crime subject to Military Court. The problem is Indonesia did not change the jurisdiction of the Military Court and still acknowledges the Military Court Law for the formal proceedings. Consequently, Military Courts still retain their jurisdiction and therefore provide privileges by overlapping jurisdiction with the General Court.

Based on the background above, the author set the research formulation is as follows.

1. How is Equality Before the Law stipulated in Article 28 D Verse 1 of the 1945 Constitution applied in Indonesia's court of law? 
2. How Article 9 Verse 1 of Law Number 31 Year 1997 Concerning Military Court is against the principle of Equality Before the Law which is stipulated in Article 28 D Verse 1 of the 1945 Constitution?

\section{ANALYSIS \& DISCUSSION}

\subsection{Judicial System in Indonesia}

The courts in Indonesia are bounded by two principles in its exercise of power which are relative competence and absolute competence. Relative Competence is the exercise of power based on territorial jurisdiction. Absolute jurisdiction means the exercise of the court's power based on the disputed matter of the case. Therefore in assessing cases, the courts must analyze whether they have relative competence and whether they satisfy their absolute competence in the case.

In its application, as a state based on law, Indonesia is obliged to exercise an independent judiciary in its state to ensure the exercise of its judicial system. Article 24 Verse 1 of UUD 1945 stipulates that the Judiciary power in Indonesia is an independent power to establish judicial systems by upholding the law and justice. Furthermore, Verse 2 of the same Article stipulates that the judicial power in Indonesia shall be administered through General Courts, Religious Court, Military Court Administrative Court, and the Constitutional Court.

\section{A. General Courts}

The General Courts is a division recognized in implementing the judiciary power through law and justice under UUD 1945. Its formal proceedings in implementation are regulated through:

1. Law Number 2 Year 1986 Regarding General Court ["General Court Law"]

2. Law Number 8 Year 2004 Regarding the first Change of Law Number 2 Year 1986 Regarding General Court [" ${ }^{\text {st }}$ Change of General Court Law"]

3. Law Number 49 Year 2009 Regarding the Second Change of Law Number 2 Year 1986 Regarding General Court [" $2^{\text {nd }}$ Change of General Court Law"]

Article 2 of $1^{\text {st }}$ Change of General Court Law stipulated that General Courts are the institutions that exercise the judiciary power for people who seek justice generally. The people meant are any people under the Republic of Indonesia nationality and other nationality (depending on the merits of the case and the formal proceedings law that govern each General Court). The hierarchy is determined in Article 1 Verse 1 of $2^{\text {nd }}$ Change of General Court Law where it consists of the district court and one level above is the high court. Furthermore, according to Article 2 of the $2^{\text {nd }}$ Change of General Court Law, the district court is located at the city level while the high courts are located in the capital city of a province in Indonesia. The General Court allows specialization of the court depending on the substantive matter of the case it adjudicates. Elucidation of Article 1 Verse 2 Number 1 of $2^{\text {nd }}$ Change of General Court Law stipulated that the specialized courts are Juvenile Court, Commerce Court, Human Rights Court, Corruption Cases Court, Industrial Relations Court, and Fishery Court.

Normally, cases such as criminal charges and a civil lawsuit would be under the jurisdiction of the General Courts. The formal proceedings of each court will depend on which jurisdiction of the court it belongs to. The formal proceedings in a criminal court and civil lawsuit court differ from each other and are subject to different formal laws.

\section{B. Religious Court}

Equal to General Courts, Religious Courts are also recognized as a body in which judiciary power is implemented as mandated by UUD 1945. Its formal proceedings are mainly regulated by:

1. Law Number 7 Year 1989 Regarding Religion Court ["Religious Court Law"]

2. Law Number 3 Year 2006 Regarding the First Change of Law Number72 Year 1989 Regarding Religion Court [" $1^{\text {st }}$ Change of Religious Court Law"]

3. Law Number 50 Year 2009 Regarding the Second Change of Law Number 7 Year 1989 Regarding Religion Court [" $2^{\text {nd }}$ Change of Religious Court Law"]

Article 1 Verse 1 of $2^{\text {nd }}$ Change of Religion Court Law stipulated that the Religion Court is for people with Islam religion and adjudicating certain matters. As reiterated in Article 49 of the $1^{\text {st }}$ Change of Religion Court Law, the matters of people with Islam religion that can be adjudicated are marriage, inheritance, will, 
hibah, wakaf, zakat, shadaqah, and syari'ah economy. Should a person with an Islam Religion dispute on matters as stated previously, then he/she is subject to Religion Court.

\section{Administrative Court}

Equal to General Court and religious court, the Administrative Court is also recognized under the constitution as a body to implement judicial power. The Administrative Court is mainly governed by:

1. Law Number 5 Year 1986 Regarding Administrative Court Law ["Administrative Court Law"]

2. Law Number 9 Year 2004 Regarding Change to Law Number 5 Year 1986 Regarding Administrative Court Law [" $1^{\text {st }}$ Change of Administrative Court Law"]

3. Law Number 51 Year 2009 Regarding Second Change of Law Number 5 Year 1986 Regarding Administrative Court Law [" $2^{\text {nd }}$ Change of Administrative Court Law"]

Administrative court laws adjudicate cases concerning administrative disputes. According to Article 10 of the $2^{\text {nd }}$ Change of Administrative Court Law, administrative disputes are defined as disputes that arise of administrative matters between persons with state administrative officials or bodies as a result of an administrative decision.

As the matter disputed in this court of law is different from the previous two, the decisions of an administrative court are unique and different from other courts recognized under the UUD 1945. The decisions of an administrative court will contain the elements of the decision being a written decision, State Administrative officials and body, legal act of administrative law, positive law, and concrete, individual, final, and a legal consequence to a person or body.

\section{Military Court}

Equal to General Court, Religion Court, and Administrative Court, Military Court is recognized under UUD 1945 and mainly regulated through Law Number 31 Year 1997 Regarding Military Court Law. According to Article 9 Verse 1 of Military Court Law, the Military Court Law adjudicates cases of criminal crime committed by military personnel of the Indonesia Armed Forces. Should there be more than one court that is under the jurisdiction to adjudicate a case, then according to Article11, the first court that exercises jurisdiction over the case will retain jurisdiction over the case.

Substantively, the matters of law under the jurisdiction of Military Courts are from the IPC and Indonesian Military Penal Code [IMPC]. Formally, the proceedings of a Military Court are provided in chapter four of the Military Court Law. The judges in Military Court consist mainly of three judges in all the instances except for Military Conflict Courts. Under Article 12 of Military Court Law, the Military Court would consist of the following bodies and levels of court stipulated from the lowest to the highest:

1. Military Court

2. High Military Court

3. Main Military Court

4. Conflict Military Court (this court is an exception in the hierarchy as it conducts trials during conflicts and therefore only consist of a single judge).

The above explanation of Military Court Law provides that the process of the court will be that investigators and helper-investigator will investigate acts allegedly being a breach of law considered as either a military or general crime. An arrest and detainment can be conducted by the Investigator under Article 75-81 should it be deemed necessary. The charges of the case then are given to the Head of the Military Court in that area, and a three-membered judge will be formed. A trial then will proceed for the judges to deem whether the defendant is indeed guilty or not.

\section{E. Supreme Court}

The Supreme Court in Indonesia is the highest in Indonesia and retains jurisdiction in adjudicating cases of cassation, disputes regarding the Authority to adjudicate cases, and the request of a case review. According to Article 24 Verse 2 of the 1945 Constitution, the Supreme Court of Indonesia is the highest body in administrating justice through its court. Therefore, the courts previously mentioned are all under the jurisdiction of the Supreme Court. The Supreme Court is governed by the following laws which are:

1. Law Number 14 Year 1985 Regarding Supreme Court ["Supreme Court Law"] 
2. Law Number 5 Year 2005 Regarding Change of Law Number 14 Year 1985 Regarding Supreme Court [ “ $1{ }^{\text {st }}$ Change of Supreme Court Law"]

3. Law Number 3 Year 2009 Regarding Second Change of Law Number 14 Year 1985 Regarding Supreme Court ["Second Change of Supreme Court Law"]

It needs to be understood that the position of the Supreme Court is the highest among the courts previously mentioned. Therefore, as previously mentioned, the jurisdiction of this court is in regards to the General Court, Military Court, administrative court, and religious court are all under the jurisdiction of the Supreme Court.

\section{F. Constitutional Court}

Contrary to the other courts previously mentioned, the Constitutional Court is not under the jurisdiction of the Supreme Court. The Constitutional Court in Indonesia is a special court that is different from the Supreme Court concerning its structure. The Constitutional Court is governed by two laws which are:

1. Law Number 24 Year 2003 Regarding Constitutional Court ["Constitutional Court Law"]

2. Law Number 8 Year 2011 Regarding Change of Law Number 24 Year 2003 Regarding Constitutional Court [" $1^{\text {st }}$ Change of Constitutional Court Law"]

According to Article 10 of Constitutional Court Law, the Constitutional Court in Indonesia retains jurisdiction over cases regarding the review of laws against the 1945 Constitution, disputes regarding state institutions recognized under the 1945 Constitution, dismiss a political party, election-related disputes and provide decisions regarding the opinion of the People's Representative Assembly concerning the impeachment of the President.

\subsection{Applying Equality before the Law in Indonesia according to Article 28 D Verse 1 of the 1945 Constitution in Indonesia's Court of Law}

\section{A. Applying Equality before the Law in Indonesia's Court of Law}

As elucidated in the previous section, Indonesia as a state law (state based on law), is obliged to treat its citizens equally including in the administration of justice through its courts of law. This section is intended to analyze how Equality Before the Law is administered in the courts of law in Indonesia. The author argues that the Equality Before the Law principle is applied in the courts of law through its absolute competence of each respective court.

Absolute competence means that the court's jurisdiction is based on the disputed matter of the case. A case when presented before the court must be assessed whether the court in question has jurisdiction over the matters of the case. The jurisdiction over the matters of the case is regulated by law regarding the court itself. Furthermore, the author of this thesis argues that there is a reason why it is termed as "absolute" competence.

In Indonesia, there are six major courts as prescribed by Article 24 verse 2 . These courts are the General Courts, religious courts, Military courts, administrative courts, and constitutional courts. All of the courts as mentioned before are subject to be under the Supreme Court, whereas the Supreme Court is the highest governing body to administer justice for those who seek it. First of all, the author will analyze the absolute competence of each court, including the Supreme Court, as prescribed by the law governing the exercise of each of the respective court. However, it is to be noted that this section will not discuss and analyze the absolute competence of Military Court Law which is prescribed under Article 9 Verse 1 of Military Court Law. The discussion on absolute competence of Military Court will be discussed in the next section because Article 9 Verse 1 of Military Court Law, the author of this thesis argues, is against Article $28 \mathrm{D}$ verse 1 of the 1945 Constitution which when compared and contrast to, shows how it is against the principle of equality.

The absolute competence of General Courts can be seen through Article 50 of General Court Law which elucidates that the court exercises jurisdiction over criminal cases and civil lawsuits. Under its absolute competence, the General Courts, therefore, exercise jurisdiction over a case where the disputed matter is either criminal or civil lawsuit in its nature. Those cases would usually fall under the Indonesia Civil Code ["ICC"].

Abiding by the arguments of the author regarding the meaning as to why it is called absolute competence, the author argues that the General Courts are strictly allowed only to adjudicate cases regarding criminal cases or civil lawsuits. If the disputed matters of the case are not prescribed by Article 50 of General 
Court Law, then the General Court will have no jurisdiction, therefore authority, in adjudicating the case. Therefore, the author concludes this argument by pointing out the absolute competence of the General Court.

The second court to be analyzed is the religious court. The absolute competence of the religious court is prescribed under Article 1 Number 47 of $1^{\text {st }}$ Change of Religious Court Law which elucidates that the religious court can exercise jurisdiction over persons who holds Islam as their religion and concerns the following matter:

\section{Marriage \\ 2. Inheritance \\ 3. Testaments/Will \\ 4. Grants \\ 5. Wakaf \\ 6. Zakar \\ 7. Infaq \\ 8. Shadaqah \\ 9. Syariah Economy}

Therefore, the author argues that it is already evidently clear that in a case where the disputed matters fall within the matter mentioned above, the religious court can exercise jurisdiction over the case. As the author has said previously, above is the absolute competence. Therefore, if the disputed matters of a certain case are not within the matter mentioned above, then the religious court has no jurisdiction and therefore, authority, over the case.

The court to be analyzed next is the administrative court. The absolute competence of the administrative court can be found in Article 47 of Administrative Court Law which stipulates that the court retains jurisdiction over cases regarding state administration. The definition of state administration can then be found in Article 1 Number 1 Regarding Changes of Article 1 Point 7 where state administration is state administration for the purpose to execute the obligations of the central and regional government. Owing to the definition of absolute competence, the administrative court can only retain jurisdiction over cases concerning state administration whereas state administration is meant as state administration for the purpose to execute obligations of the central and regional government.

The next court to be analyzed is the Supreme Court. The Supreme Court heads over the other court mentioned and elucidated previously which are General Courts, Military Courts, religious courts, and administrative courts. The Supreme Court's absolute competence is to decide on cases that entered the cassation stage and resolve matters regarding the court's jurisdiction. Owing to the definition of absolute competence, the Supreme Court is only able to decide cassation cases and decide matters regarding a dispute in a court's jurisdiction. Aside from this, they are unable to exercise jurisdiction.

The last court's absolute competence to be analyzed is the Constitutional Court. As elucidated in Chapter 2 the Constitutional Court is a court separate and not under the Supreme Court. Its absolute competence can be found in the cases it can exercise its jurisdiction which are review laws against the 1945 Constitution, disputes regarding state institutions recognized under the 1945 Constitution, dismiss a political party, election-related disputes, and provide decisions regarding the opinion of the People's Representative Assembly concerning the impeachment of the President.

Out of all the absolute competence discussed above, the absolute competence has created a somewhat, the author argues, a scheme where their absolute competence creates a condition where a person is forced to be only liable under a certain court's jurisdiction for a certain case. It is not possible, under the same disputed merits of the case, for more than one court to exercise jurisdiction. To make the author's argument clear, the authors have provided a simple diagram of how absolute competence creates such a scheme.

Having discussed and analyzed the absolute competence of each court, simplified through the diagram, next shall be discussed how through the absolute competence Equality Before the Law principle is applied in the courts of law in Indonesia. The author argues that the absolute competence of the court above creates an ideal reality where every citizen is equal which concurs with the Equality Before the Law principle.

Therefore, to each individual, they are all equal because the opportunity for them to seek justice is all 
limited under a single court's jurisdiction depending on their legal case. This is how the author argues, Equality Before the Law principle under Article $28 \mathrm{D}$ Verse 1 of The 1945 Constitution is applied in the court of law in Indonesia. The individuals have no choice and are somewhat forced to submit under a single jurisdiction and this applies to all of the individuals. The author concludes this section of analysis by concluding that with only being able to submit under a single jurisdiction of a court, no one will be benefitted against the others and there exists no opportunity for them to be benefitted.

\section{B. Article 9 Verse 1 of Indonesia Military Court Law is against Equality before the Law Principle in Article 28 D of 1945 Constitution}

Article 9 Verse 1 of Military Court Law as the basis for Military Court's Absolute Competence

The author argues first of all that Article 9 Verse 1 of Military Court Law is the basis of its absolute competence such as the other courts described above. Article 9 Verse 1 of Military Court mentions the following matter:

Adjudicating a criminal act committed by a person who at the time of committing the criminal act:

\section{a. Soldier;}

b. which based on the law is equated with Soldier;

c. a member of a group or service or body or who are treated as soldiers or considered as Soldiers by law;

d. a person who is not included in the categories in letters a, b, and c but upon the decision of the Commander with the approval of the Minister of Justice must be tried by a court within the context of military justice

The fundamental notion of the Military Court's absolute competence in Indonesia is that the Military Court retains jurisdiction over crimes, both general and military crimes, which are conducted by members of the armed forces and those who are equally treated and regarded as military members. Therefore, the author submits that it is clear and evident that the absolute competence of the Military Court in Indonesia is military members committing a crime.

Article 9 of military court law simply refers to "crimes" committed which does not explicitly detail whether it is military crimes or general crimes. The background section also elucidated that the Military Law and People's Representative's decision purposely separated the court's jurisdiction in which for general crimes, military members would be adjudicated in general courts and military crimes would be adjudicated by a military court. However, the author would like to argue that in practice, the military court's absolute competence does indeed exercise jurisdiction over general crimes committed by military members. The author will provide three recent cases to show that the military court does indeed retain absolute competence over general crimes committed by the military members.

The first case to be analyzed is the Decision of Jakarta Military Court II Number 16-K/PMTII/AD/II/2019. In 2019, according to the decision, Infantry Lieutenant Colonel Sri Gamal Saptono was charged under Article 372 of IPC. The decision ultimately decided to stop the proceedings due to the absence of the defendant. However, the author would like to show that in this case, the Military Court retained absolute jurisdiction over a military member who was charged with committing embezzlement. Article 372 of embezzlement is concluded in IPC; in which it is considered a general crime.

The second case to be analyzed is the Decision of Surabaya Military Court III Number 68K/PMT.III/BDG/AD/VII/2018. In 2017, First Infantry Frans Pattian was found guilty of the crime of persecution under Article 351 Verse 1 of IPC. Once again, in this case, it is clear that the court retains jurisdiction over general crimes committed by military members. It can be seen through the case's main charge towards the defendant which is considered a general crime because Article 351 Verse 1 is the crime of persecution regulated under IPC.

\section{Article 9 of Military Court Law is against Equality before the Law Principle under Article 28 D Verse 1 of the 1945 Constitution}

This section will analyze how the Military Court's absolute competence in Article 9 of Military Court Law is against the Equality Before the Law principle under Article 28 D Verse 1 of the 1945 Constitution. In analyzing this section, the author submits that it is against the Equality Before the Law principle as it is against the characteristics of the Indonesian courts of law, which is single jurisdiction with no opportunity characteristic. Therefore, Article 9 Verse 1 of Military Court Law creates privileges that can be directed both 
ways, for those under the jurisdiction of the Military Court and General Court.

The author will now analyze how Article 9 Verse 1 of Military Court Law is against Equality Before the Law principle as elucidated in Article $28 \mathrm{D}$ Verse 1 of the 1945 Constitution. To prove the author's argument that it is indeed against Equality Before the Law, the author argues that it is evident through analyzing the circumstances and the reality Article 9 Verse 1 of Military Court Law creates.

Article 9 Verse 1 of Military Court Law, when applied, creates a legal situation where military members can either submit to the General Court or Military Court. This legal situation is rooted based on the absolute competence of both courts where the General Courts try individuals, including those of military members, who commit general crimes and the Military Court tries military members for committing a general crime.

The Military Court's absolute competence, as elucidated before, retains jurisdiction over military members who commit crimes that are both general in their nature and those that are considered military crimes. The author then would like to point out that it was the Military Court that recognizes the jurisdiction of multiple courts. Article 11 of Military Court Law recognizes that it is possible that in a certain case, other courts may retain jurisdiction over the military members regarding the crimes he/she committed. On the other hand, nowhere in the laws governing the General Court, it is allowed, neither it recognize the fact that other courts may retain jurisdiction among individuals who commit general crimes. Therefore, the author submits, through the simple analysis of each of the laws governing the courts that it is obvious that the Military Court meant by purpose and by full intention to create a legal situation where military members can be subject to two court's jurisdiction.

The rationale then establishes that when a military member, under the Military Court, receives a favorable decision/judgment, then he/she is privileged because they at the same are also liable to be under the jurisdiction of the General Court, but the civilians who are limited under the General Court there are unable to enjoy the possibility to be benefitted in the Military Court. The civilians, to be equally fair should also enjoy the opportunity to be liable under two jurisdictions giving them the same opportunity as the military members.
Ultimately, Article 9 Verse 1 of Military Court Law is clearly against the single jurisdiction with no opportunity characteristic and therefore, because it creates an opportunity for the military members to win a favorable decision in the Military Courts. As previously analyzed, it is clear that having more than one jurisdiction of the court then amounts to the possibility in which one of them will provide a favorable decision against the others. Therefore, Article Verse 1 of Military Court Law is against the principle of Equality Before the Law principle as elucidated in Article $28 \mathrm{D}$ Verse 1 of the 1945 Constitution.

\section{CONCLUSION}

Indonesia as state law is obliged to implement the principle of Equality Before the Law. Therefore, no one can be privileged because they are only able to submit themselves to one court should they seek justice.

In conclusion, Article 9 Verse 1 of Military Court Law is against the Equality Before the Law principle under Article 28D Verse 1 of the 1945 Constitution. Article 9 Verse 1 of Military Court Law is against the principle of Equality Before the Law because it deviates and breaches the single jurisdiction with no opportunity characteristics, a characteristic common in applying Equality Before the Law principle in other courts.

\section{REFERENCES}

Abdullah, Rozali. 1992. Hukum Acara Peradilan Tata Usaha Negara. Jakarta: Rajawali Pers.

Angkouw, Kevin. 2014. "Fungsi Mahkamah Agung Sebagai Pengawas Internal Tugas Hakim Dalam Proses Peradilan." Lex Administratum 2 (2): 1.

Dicey, A. V. (With an introduction by E. C. S. Wade). 1975 Introduction to the Study of the Law of the Constitution. London and Basingtoke: The Macmillan Press LTD.

Faiz, Pan Mohamad. 2018. "Terjemahan Resmi UUD 1945”, Majalah Konstitusi, Mahkamah Konstitusi.

Fauzan, M. 2007. Pokok-Pokok Hukum Acara Peradilan Agama dan Mahkamah Syari'ah di Indonesia. Jakarta: Kencana.

Hadi, Syofyan. 2016. "Mengkaji Sistem Hukum Indonesia (Kajian Perbandingan Dengan Sistem Hukum Lainnya." DiH Jurnal IImu Hukum 12 (24) : 165-166. https://doi.org/10.30996/dih.v12i24.2244

Ivan, Randang S. 2016. "Tinjauan Yuridis Tentang Peranan Identitas Domisili Dalam Menentukan Kompetensi Relatif Pengadilan." Lex Privatum 4 (1).

Kaligis, O.C. 2005. Mahkamah Konstitusi Praktik Beracara \& Permasalahannya, Jakarta: O.C Kaligis \& Associates.

S.F.Marbun. 2003. Peradilan Tata Usaha Negara. Yogyakarta: Liberty.

Salam, Moch Faisal. 2002. Hukum Acara Peradilan Miilter Di Indonesia. Bandung: Mandar Maju.

Sayuti. 2011. "Konsep Rechtsstaat Dalam Negara Hukum Indonesia (Kajian Terhadap Pendapat Azhari)." Nalar Fiqh Jurnal Kajian Ekonomi Islam Kemasyarakatan 4 (2) : 92-93. 
Simamora, Janpatar. 2014. "Tafsir Makna Negara Hukum Dalam Perspektif Undang-Undang Dasar Negara Republik Indonesia Tahun 1945." Jurnal Dinamika Hukum 14 (3) : 557. https://doi.org/10.20884/1.jdh.2014.14.3.318
Subekti. 1983. "Sistem Peradilan Indonesia". Jurnal Hukum dan Pembangunan 13 (5): 404.

https://doi.org/10.21143/jhp.vol13.no5.985

Yuslim. 2015. Hukum Acara Peradlian Tata Usaha Negara. Jakarta: Sinar Grafika.

Received on 25-08-2021

Accepted on 10-10-2021

Published on 28-10-2021

https://doi.org/10.6000/1929-4409.2021.10.163

(c) 2021 Ginting and Christian; Licensee Lifescience Global.

This is an open access article licensed under the terms of the Creative Commons Attribution License (http://creativecommons.org/licenses/by/4.0/) which permits unrestricted use, distribution and reproduction in any medium, provided the work is properly cited. 